\title{
Finite Element Analysis of Strengthened Reinforced Concrete Beams
}

\author{
Sura A. Majeed \\ Assistant Lecturer \\ Civil Engineering Department-Mosul University \\ Mosul-Iraq
}

\begin{abstract}
This paper presented the application of nonlinear finite element models in the analysis of rectangular reinforced concrete beams strengthened with ferrocement in the form of $U$-jacket by using ANSYS software. The numerical results are compared with the corresponding experimental results of unstrengthened beams. The comparisons are carried out in terms of load- deflection curves at mid-span, and failure loads. The predicted results of reference beam are found to be in good agreement with the experimental results. Effect of number of layers of wire mesh on the strength of analyzed beams strengthened with ferrocement jackets has been studied. The same beam is also analyzed after strengtheing it with U-jacket sheets of Carbone Fiber reinforced Polymer (CFRB) and the predicted results are compared with that of the corresponding beams strengthened with ferrocement jackets. The strengthened beams have shown a remarkable improvement in their performances in terms of load deflection and ultimate load. The Carbone Fiber Polymer U-jacket greatly improved the beam ultimate failure load by about $37.44 \%$.

Keywords : Beams, CFRP, Finite Element, Ferrocement, Strengthening.

تحليل العتبات الخرسانية المسلحة المقواة باستخدام طريقة العناصر المحدة

$$
\begin{aligned}
& \text { سرى عبد الرزاق مجيد }
\end{aligned}
$$

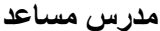$$
\text { قسم الهنلسة المدنيةجامعة الموصل }
$$

يثمل البحث الحالي تطبيق التحليل غير الخطي باستخدام طريقة العناصر المحددة لتحليل العتبات الخرسانية المقواة

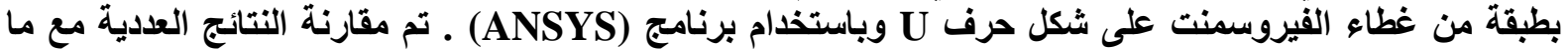

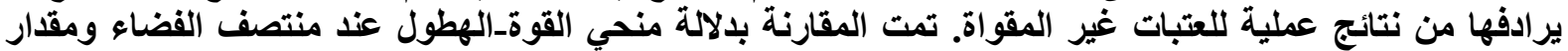

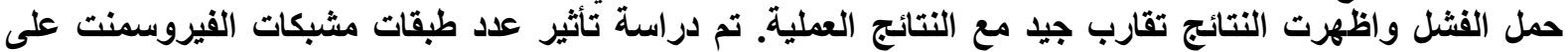

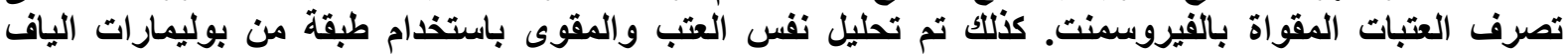

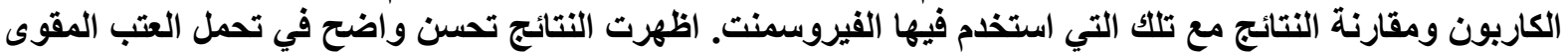

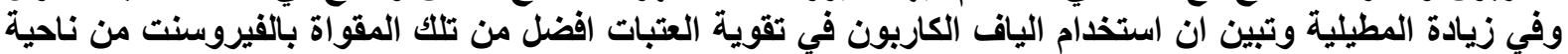

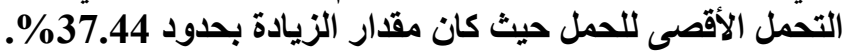




\section{Introduction}

Strengthening of reinforced concrete structural members is an important task in the field of structural maintenance. Reinforced concrete structures need to be strengthened due to a number of factors which include the increase in loads as a result of functional changes of the structures, overloading, under-designed of existing structures or due to the lack of quality control. Different types of strengthening materials are available in the market for this purpose, these include ferrocement, sprayed concrete, steel plate and fiber reinforced polymer (FRP) laminates. At present ferrocement jackets is one of the most commonly used due to their easy availability, economy, durability, and their property of being cast to any shape without needing for formwork.

Many experimental studies have been conducted in recent years to strengthen flexural members by using various materials. Andrew and Sharma [1] in an experimental study compared the flexural performance of reinforced concrete beams repaired with conventional method with that of ferrocement. It has been concluded that beams repaired by ferrocement showed superior performance both at the service and ultimate load stages. The flexural strength and ductility of beams repaired with ferrocement was reported to be greater than the corresponding original beams. Beams rehabilitated with ferrocement jackets have shown a better performance in terms of ultimate strength, first crack load, crack width, ductility and rigidity of the section. It was observed that the cracking and ultimate strength increased by 10 percent and 40 percent respectively. The jacketing increases the rigidity of the beams and leads to $29-37 \%$ reduction in deflection. The crack width of the composite beams and rehabilitated beams decreases on an average by 42 percent and 36 percent respectively[2]. The addition of thin layer of ferrocement to a concrete beam enhances its ductility and cracking strength. Composite beams reinforced with square mesh exhibit better overall performance compared to composite beams reinforced with hexagonal mesh. An increase in the number of layers improves the cracking load of the composite beams in both cases[3-5].It has been found in Ref [6] that the moment carrying capacity increased by 9 per cent and 15 per cent for balanced and over reinforced sections respectively. The ultimate strength of the reinforced concrete beams, which failed due to overloading and were repaired using ferrocement laminate, is affected by the level of damage sustained prior to repairing. However, ultimate strength, ductility ratio and energy absorption have been reported to improve after the repair. The steel ratio used in the repair layer has a great influence on the amount of gain in the resisting moment, ductility ratio and energy absorption. The higher the steel ratio the higher the gain in resisting moment and energy absorption; conversely, the ductility ratio was found to be decreased with the increase in steel ratio [7]. Although traditional empirical methods remain adequate for ordinary design of reinforced concrete members, the wide dissemination of computers and the development of the finite element method have provided means for analysis of much more complex systems in a much more realistic way. ANSYS [8] provides a dedicated three-dimensional eight nodded solid isoparametric element, Solid65 can model the nonlinear response of brittle materials based on a constitutive model for the triaxial behavior of concrete based on Williams and Warnke constitutive model [9]. The present work presented the application of nonlinear finite element models for the analysis of rectangular reinforced concrete beams strengthened with either ferrocement or jacket CFRP in the form of U-shape by using ANSYS software (version 10) [10]. The study involved investigating the effect of number of ferrocement wire mesh layers on the overall response of reinforced concrete beams and to compare the efficiency of strengthened beams with CFRP laminates with that of ferrocement. 


\section{Notation}

$\boldsymbol{E}_{\boldsymbol{c}}=$ modulus of elasticity of concrete.

$\boldsymbol{f}_{\boldsymbol{c}}=$ stress at any strain $\boldsymbol{\varepsilon}$.

$\boldsymbol{f}_{\boldsymbol{c}}^{\prime}=$ ultimate uniaxial compressive strength.

$f_{t}^{\prime}=$ ultimate uniaxial tensile strength.

$\boldsymbol{\varepsilon}_{\circ}=$ strain at the ultimate compressive strength $\boldsymbol{f}_{\boldsymbol{c}}^{\boldsymbol{\prime}}$.

$\boldsymbol{\varepsilon}_{\boldsymbol{c r}}=$ ultimate compressive strain (crushing strain).

$\boldsymbol{\varepsilon}_{\boldsymbol{1}}=$ strain corresponding to $\left(0.3 \boldsymbol{f}_{\boldsymbol{c}}^{\prime}\right)$.

$\boldsymbol{v}=$ Poisson's ratio.

$V_{\boldsymbol{f}}=$ volume fraction of reinforcement.

\section{Finite Element Modeling}

The calibration of finite element model included checking the model by comparing the nonlinear finite element results of a reinforced concrete beam with the corresponding experimental results available in reference [11].

\section{Concrete and Mortar}

Solid65 element was used to model the concrete and mortar. This element has eight nodes with three degrees of freedom at each node - translations in the $\mathrm{x}, \mathrm{y}$, and $\mathrm{z}$ directions. This element is capable of plastic deformation, cracking in three orthogonal directions, and crushing. A schematic representation of the element is shown in Fig.(1). The cracking is modeled by smeared crack approach.

The adopted compressive uniaxial stressstrain relationship for concrete and mortar is
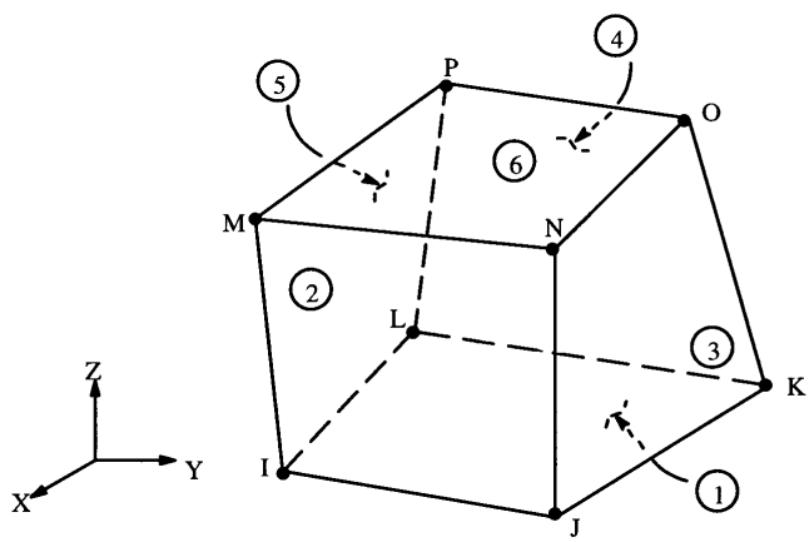

Figure 1: Solid65 element geometry the multilinear isotropic stress-strain curve shown in Fig.(2), and calculated by the relations [12]:

$f_{c}=\varepsilon E_{c}$

for

$0 \leq \varepsilon \leq \varepsilon_{1}$

$f_{c}=\frac{\varepsilon E_{c}}{1+\left(\frac{\varepsilon}{\varepsilon_{0}}\right)^{2}}$

for

$\varepsilon_{1} \leq \varepsilon \leq \varepsilon_{\circ}$

$f_{c}=f_{c}^{\prime}$

for

$\varepsilon_{0} \leq \varepsilon \leq \varepsilon_{c r}$

$\varepsilon_{\circ}=\frac{2 f_{c}^{\prime}}{E_{c}}$ 
The simplified stress-strain curve for each beam model is constructed from (13) points connected by straight lines. The curve starts at zero stress and strain. Point (1), at $0.3 f_{c}^{\prime}$, is calculated for the stress-strain relationship of the concrete in the linear range (must satisfy Hooke's law). Points (2-11) are obtained from Equation 2, in which $\boldsymbol{\varepsilon}_{\circ}$ is calculated from Equation 4. Point (12) is at $\boldsymbol{\varepsilon}_{\circ}$ and $\boldsymbol{f}_{\boldsymbol{c}}^{\prime}$. The behavior is assumed to be perfectly plastic after point (12) up to crushing strain which is taken equal to 0.003 .

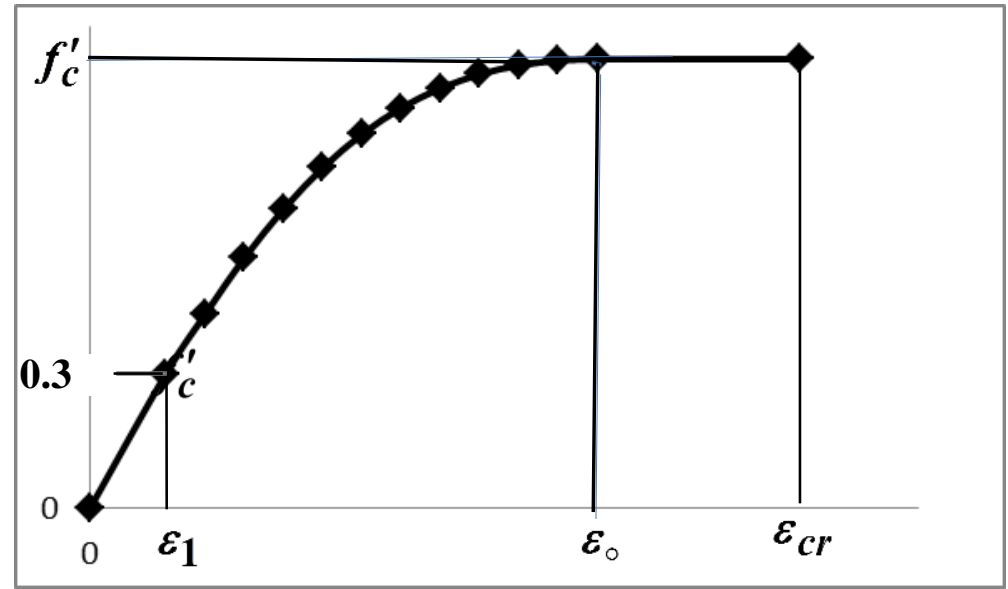

Figure 2: Multilinear compressive uniaxial stress-strain curve for concrete and mortar.

\section{Reinforcing steel}

Modeling of reinforcing steel in the finite elements is much simpler than that of concrete. Link8 element was used to model steel reinforcement. This element is a 3D spar element and it has two nodes with three degrees of freedom - translations in the $\mathrm{x}, \mathrm{y}$, and $\mathrm{z}$ directions at each node. This element is also capable of representing the plastic deformation. In the present study each steel bar element was connected between nodes of adjacent concrete solid element, this assure a perfect bond between steel and concrete. The steel is assumed to be an elastic-perfectly plastic material and identical in tension and compression.

\section{Steel plate}

To avoid stress concentration problems steel plates were added at the support and loading locations in the finite element models (similar to that in the actual beams). An elastic modulus equal to 200,000 $\mathrm{MPa}$ and Poisson's ratio of 0.3 were used for the steel plates. The steel plates were assumed to be linear elastic materials. Solid45 elements were used to model the steel plates. The geometry and node locations for this element are similar to that of element Solid65 as shown in Fig.(1)[8]. The dimensions of steel plates that were used to represent the support and loading plates are equal to $60 \mathrm{~mm}$ width* $30 \mathrm{~mm}$ thick and having length equal to the entire width of the beam.

\section{Ferrocement}

Ferrocement is a type of thin composite material made of cement mortar reinforced with uniformly distributed layers of continuous, relatively small diameter wire meshes. Solid65 concrete elements were used to model the mortar in which the wire meshes are considered to be smeared within the volume of the concrete (mortar in this case) and oriented in their proper direction. Solid 65 allows to represent the distribution of reinforcement in three different orthogonal axis[8]. Smeared cracking approach has been used to model 
cracking in ferrocement. The default parameters of tension stiffening [8] which is shown in Fig.(3) were applied for both concrete and mortar materials.

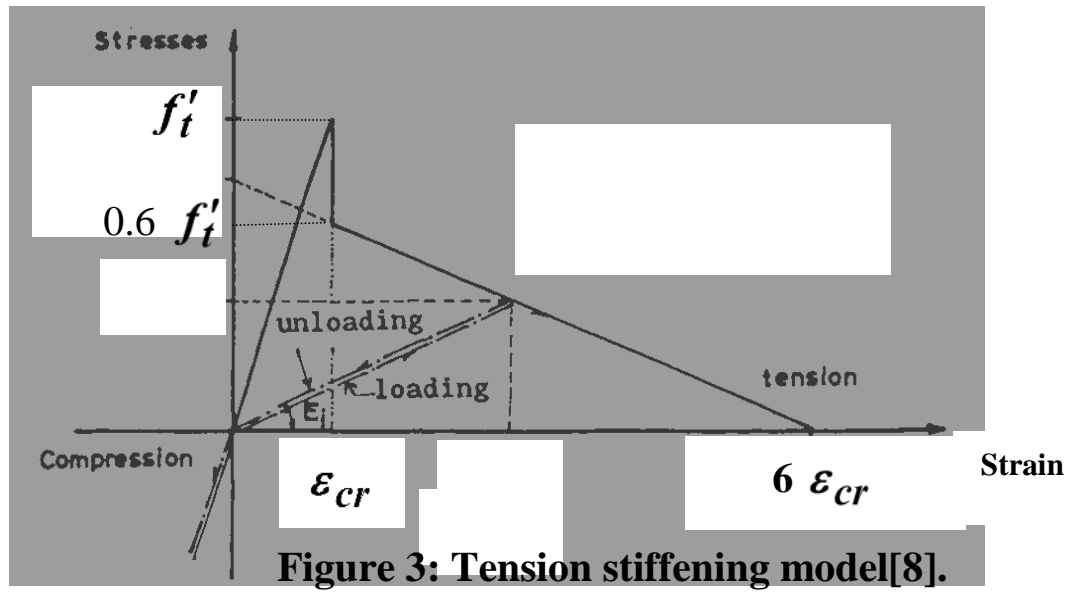

\section{CFRP Laminates}

CFRP composites are materials that consist of two constituents combined at a macroscopic level and are not soluble in each other. One constituent is the Carbon Fiber tissue, which is embedded in the second constituent, a continuous polymer called the matrix. The CFRP composites are orthotropic materials; that is, their properties are not the same in all directions. A Solid46 layered elements were used to model CFRP composites. The geometry and node locations for this element type are shown in Fig.(4).

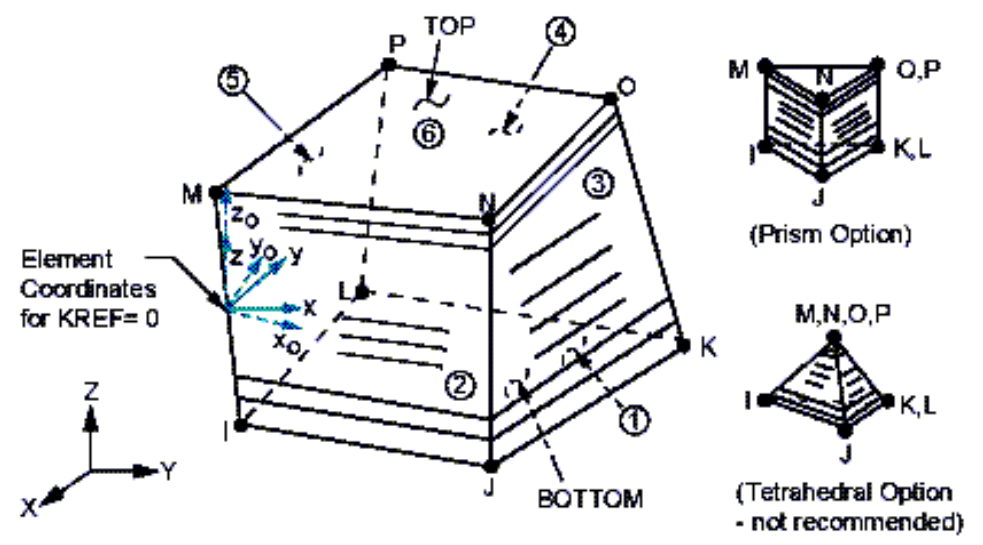

Figure 4: Solid 46 layered element geometry[8].

A summary of material properties for CFRP composites used in the present study for the finite elements modeling of the strengthened beam are given in Table 1[14].

Table 1: Material properties for CFRP composite.

\begin{tabular}{|c|c|c|}
\hline Elastic modulus $\boldsymbol{M P a}$ & Major Poisson's ratio & Shear modulus $\boldsymbol{M P a}$ \\
\hline $\mathrm{Ex}=62000$ & $v_{x y}=0.22$ & $G_{x y}=3270$ \\
$\mathrm{Ey}=48000$ & $v_{x z}=0.22$ & $G_{x z}=3270$ \\
$\mathrm{Ez}=48000$ & $v_{y z}=0.3$ & $G_{y z}=1860$ \\
\hline
\end{tabular}

\section{Geometry and material properties}

Five beams with different geometry and loading conditions are analyzed using ANSYS finite elements model. Table 2 shows details of the original and strengthened beams that were analyzed in the present study. 
Table 2 : Details of the analyzed beams.

\begin{tabular}{|c|l|c|c|}
\hline Symbol & \multicolumn{1}{|c|}{ Description } & $\begin{array}{c}\text { Ferrocement } \\
\text { and CFRP } \\
\text { thickness (mm) }\end{array}$ & $\begin{array}{c}\boldsymbol{V}_{\boldsymbol{f}} \text { of } \\
\text { wire } \\
\text { mesh }\end{array}$ \\
\hline $\begin{array}{c}\text { FEM- } \\
\text { B1 }\end{array}$ & Reference untrengthened beam[11] & 20 & 0.00113 \\
\hline $\begin{array}{c}\text { B1- } \\
\text { Ferro-1 }\end{array}$ & $\begin{array}{l}\text { Strengthen by one layer of wire mesh } \\
\text { layers for B1 }\end{array}$ & 20 & 0.00226 \\
\hline $\begin{array}{c}\text { B1- } \\
\text { Ferro-2 }\end{array}$ & $\begin{array}{l}\text { Strengthen by two layers of wire mesh } \\
\text { layers for B1 }\end{array}$ & 20 & 0.00339 \\
\hline $\begin{array}{c}\text { B1- } \\
\text { Ferro-3 }\end{array}$ & $\begin{array}{l}\text { Strengthen by three layers of wire mesh } \\
\text { layers for B1 }\end{array}$ & 20 & \\
\hline $\begin{array}{c}\text { B1- } \\
\text { CFRP }\end{array}$ & Strengthen by one layer of CFRP for B1 & 1.0 & \\
\hline
\end{tabular}

The geometry of the reference beam B1are shown in Fig.(5), and the material properties adopted in the analysis are given in Table( 3 ).

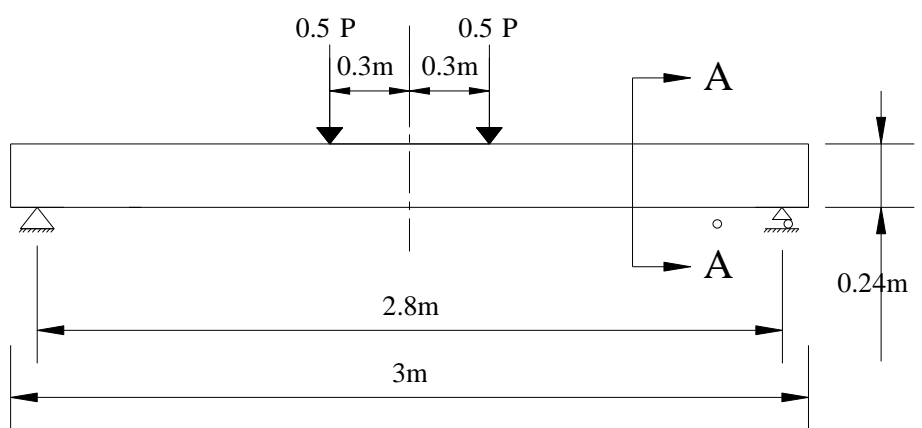

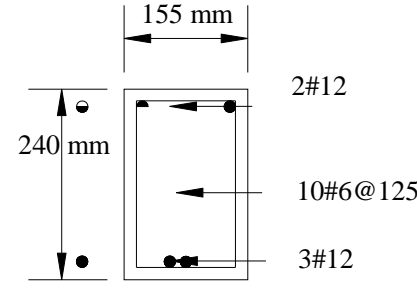

Sec. A-A

Figure 5 : Loading and geometry of the analyzed beam B1 [11].

Table 3 : Material Properties of the Analyzed Beam B1.

\begin{tabular}{|l|l|c|}
\hline Materials & Properties & Beam B1 \\
\hline Concrete [11] & Elastic Modulus (MPa) & 39200 \\
\hline Concrete [11] & Possions Ratio & 0.2 \\
\hline Concrete [11] & Compressive Strength (MPa) & 69 \\
\hline Concrete [11] & Tensile Strength (MPa) & 5.1 \\
\hline Main Reinforcement [11] & Elastic Modulus (MPa) & 200000 \\
\hline Main Reinforcement [11] & Yield Stress (MPa) & 460 \\
\hline Stirrups [11] & Elastic Modulus (MPa) & 200000 \\
\hline Stirrups [11] & Yield Stress (MPa) & 250 \\
\hline Steel Plates [*] & Elastic Modulus (MPa) & 200000 \\
\hline Steel Plates [*] & Possions Ratio & 0.3 \\
\hline Mortar [*] & Elastic Modulus (MPa) & 24300 \\
\hline Mortar [*] & Possions Ratio & 0.18 \\
\hline Mortar [*] & Compressive Strength (MPa) & 42 \\
\hline Mortar [*] & Tensile Strength (MPa) & 4 \\
\hline Wire Mesh [*] & Elastic Modulus (MPa) & 165000 \\
\hline Wire Mesh [*] & Yield Stress (MPa) & 250 \\
\hline
\end{tabular}

* assumed values 
Due to symmetry of cross-section and loading of the analyzed beams, symmetry was utilized in the finite elements analysis and only one quarter of the beam was modeled and this significantly reduced computational time and computer memory. The finite element mesh, boundary conditions and loading plates of all beams are shown in Fig.(6).

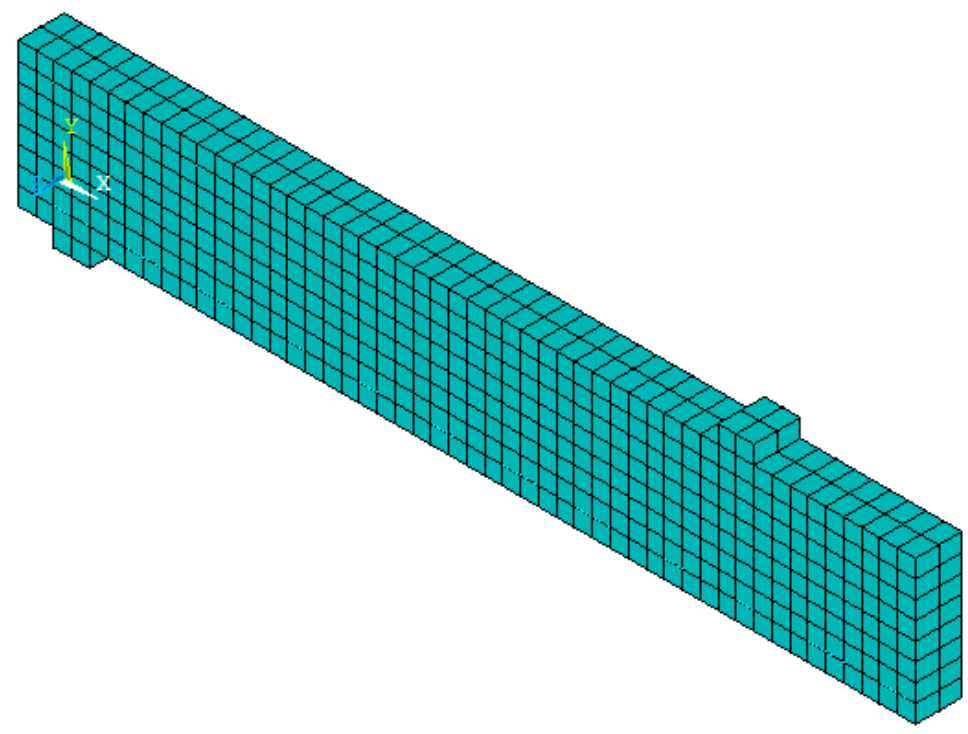

Figure 6 : Finite element mesh, support and loading plates for a quarter beam model of all beams.

\section{Validation of the Finite Element Model}

In order to validate the finite element modeling of reinforced concrete beams strengthened with either ferrocement or CFRP layers, the finite element model using ANSYS program has been applied to analyze a reinforced concrete beam tested in reference [11]. The predicted results are compared with the experimental results.

The predicted load deflection curve for unstrengthen beam B1compared with the test results is shown in Fig. (7). The numerical model predicts an ultimate load of $66.5 \mathrm{kN}$ and fairly captures the nonlinear load deflection response of the beam up to failure. The experimental ultimate load was $66.7 \mathrm{kN}$ with only $0.3 \%$ higher than the predicted value. It is clear from the predicted results that the response of the beam is linear up to the first crack which was developed at approximately $17 \mathrm{kN}$. Although the experimental response of the beam was initially slightly less stiff than the numerical one, the first visible crack is also appeared at approximately $17 \mathrm{kN}$. Beyond this point the response of the finite element model is consistent with the test data. The maximum midspan deflection of the beam B1 that was recorded in the test was of the order of $45.68 \mathrm{~mm}$; while the predicted maximum deflection at ultimate load is $37.85 \mathrm{~mm}$.

\section{Response of Strengthened Beams}

The predicted results of the analyzed beam B1 using ferrocement with different numbers of wire meshes, and that strengthened with one layer of CFRB layer are compared with that of the non-strengthened beam. The results in terms of load deflection are depicted in Fig. (8) and the comparison between the predicted ultimate loads are presented in Table (4). 
Table 4: Predicted ultimate loads for the analyzed beams.

\begin{tabular}{|l|c|c|c|c|c|}
\hline Beam No. & $\begin{array}{l}\text { Reference } \\
\text { Beam }\end{array}$ & $\begin{array}{l}\text { B1- } \\
\text { Ferro-1 }\end{array}$ & $\begin{array}{l}\text { B1- } \\
\text { Ferro-2 }\end{array}$ & $\begin{array}{l}\text { B1- } \\
\text { Ferro-3 }\end{array}$ & $\begin{array}{l}\text { B1- } \\
\text { CFRB }\end{array}$ \\
\hline Ultimate Load (kN) & 66.5 & 71.5 & 72.5 & 79.8 & 91.44 \\
\hline $\begin{array}{l}\text { Percentage } \\
\text { Difference }\end{array}$ & - & 7.5 & 9 & 20 & 37.44 \\
\hline $\begin{array}{l}\text { Maximum Deflection } \\
(\mathrm{mm})\end{array}$ & 37.85 & 43.16 & 44.5 & 44.5 & 32.5 \\
\hline
\end{tabular}

It can be notice from Fig. (8) and Table (4) that the difference of the strength enhancement by using one and two layers of wire meshes is only marginal while using 3 layers has increases both post cracking strength and ultimate load by $20 \%$. The superiority of using one millimeter layer of CFRB is quite clear in enhancing the beam stiffness and ultimate load. The deflection at ultimate load is also given in Table (4) which indicates the increase in the ductility by adding the ferrocement layer.

Some of the predicted results are presented here. The Von Misses stresses in the CFRB laminate are presented in Fig. (9) which indicates a maximum stress of about (330MPa) at a load level $(91.437 \mathrm{kN})$ which is close to failure load. This stress is far below the ultimate strength of CFRB which is normally mare than (1000MPa) and this indicate failure in the concrete material were the crack are extensively spread as shown in Fig. (10) at the same load level. The stress in steel bars of beam B1-Ferro-2 at load level $71.98 \mathrm{kN}$ is which close to failure load is presented in Fig. (11). The stresses in main reinforcement at mid span is higher than the yield strength $(460 \mathrm{MPa})$ and this is because the behavior of the steel bars was assumed to be bilinear with tangent modulus after yielding is taken equal to $30000 \mathrm{MPa}$ and ultimate strength of $(600 \mathrm{MPa})$. For the same beam and same load level, the crack pattern in the mortar is presented in Fig. (12), which indicate the widespread of the cracks in the ferrocement Mortar.

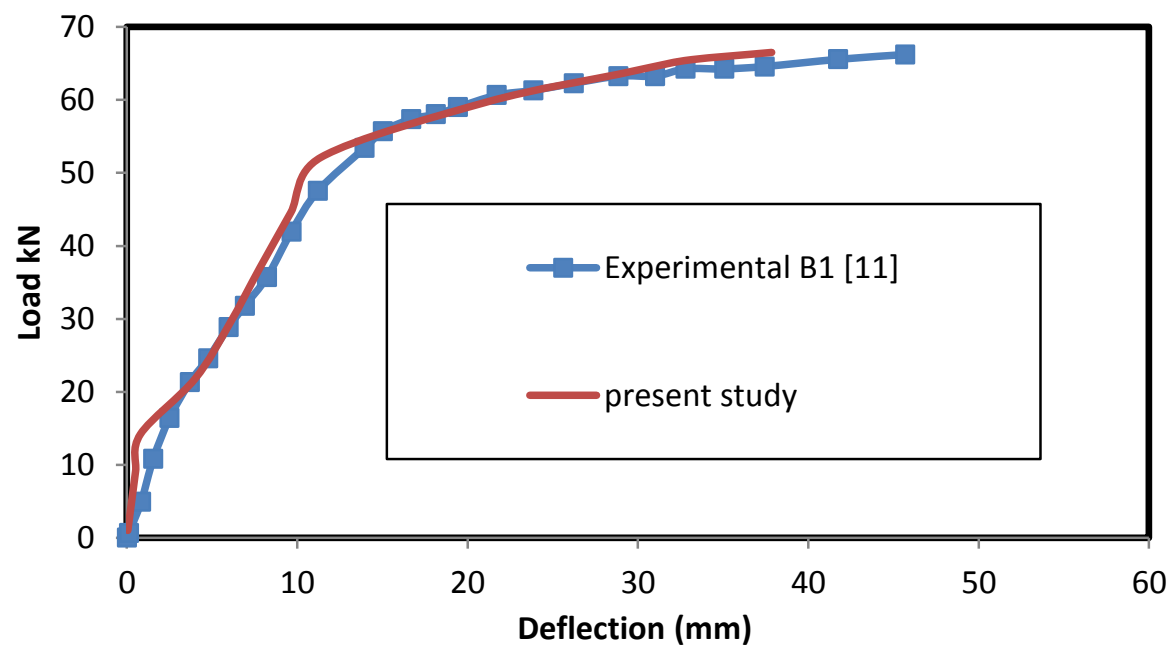

Figure 7 : Load-deflection curve for control beam B1. 


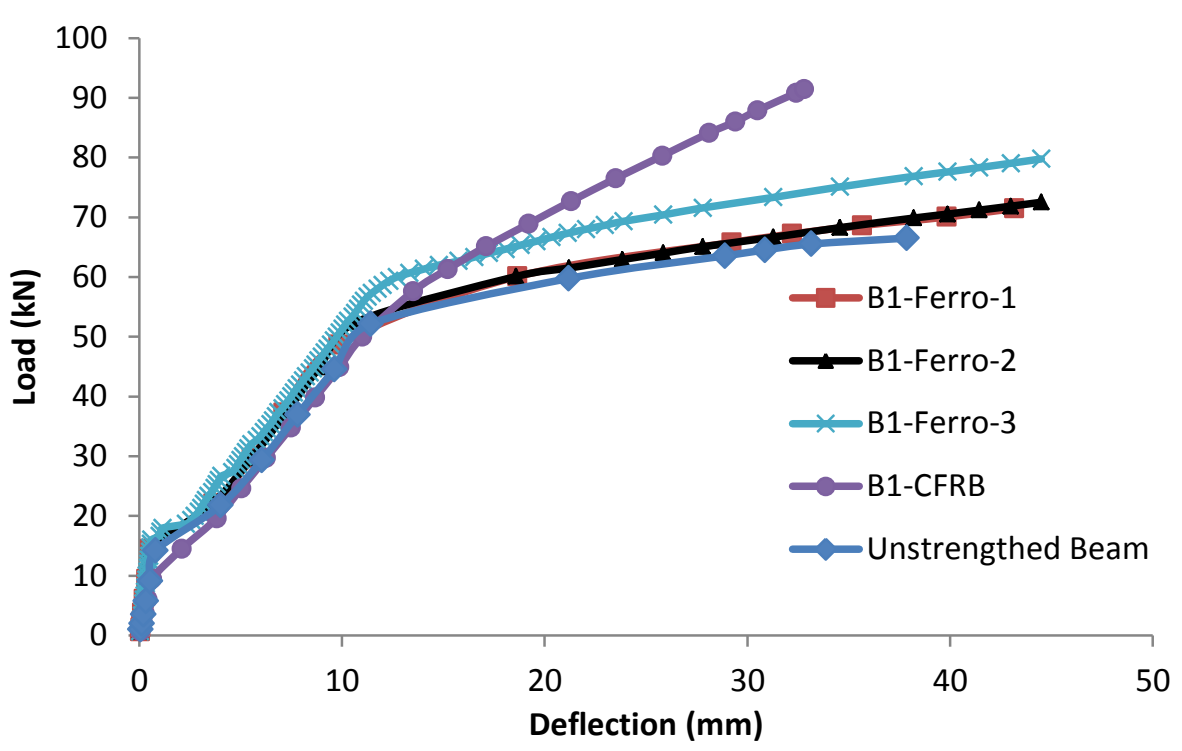

Figure 8 : Load-deflection curves for strengthened beam B1.

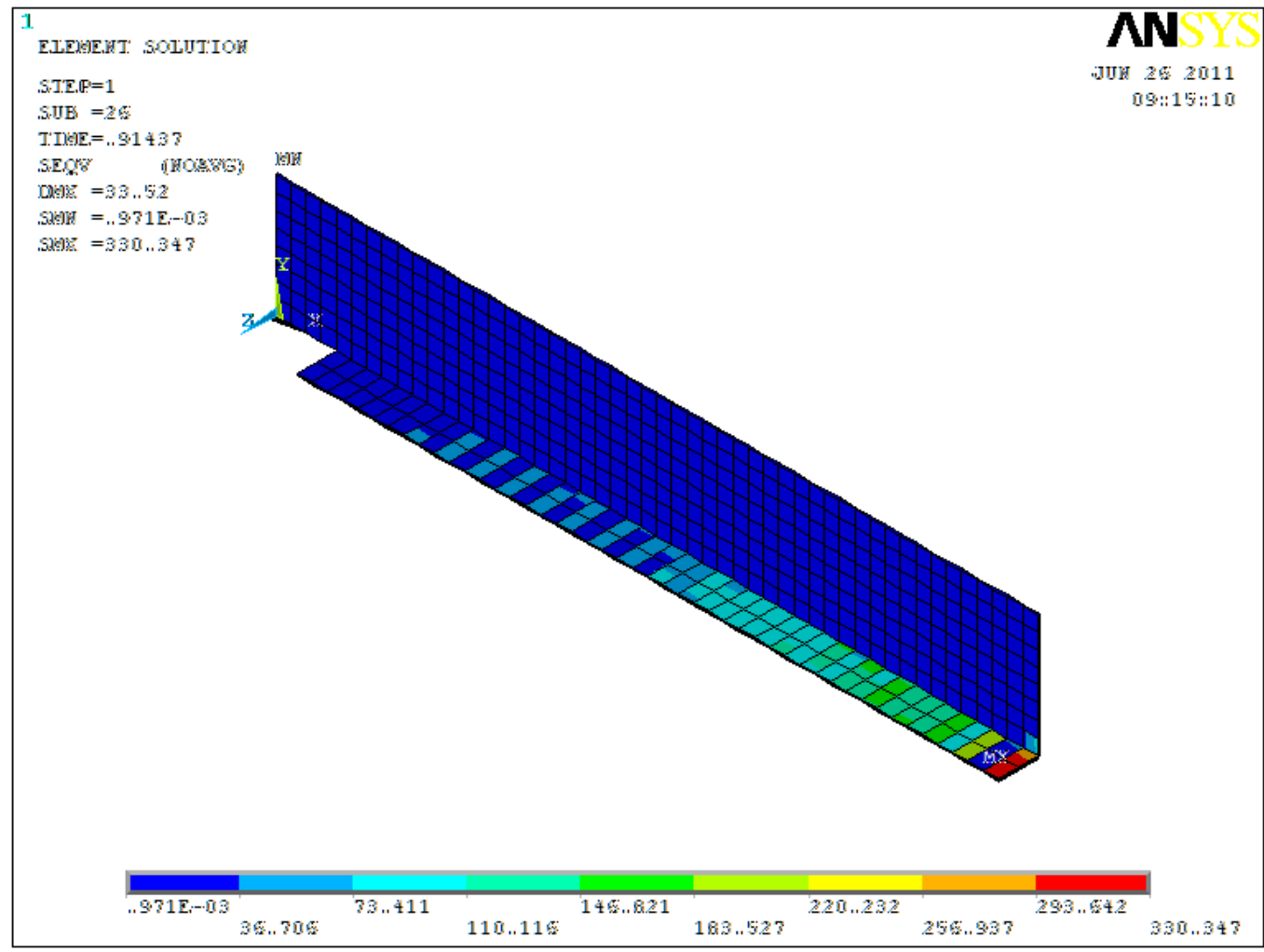

Figure 9: Von Mises Stresses in CFRB at load 91.437kN. 


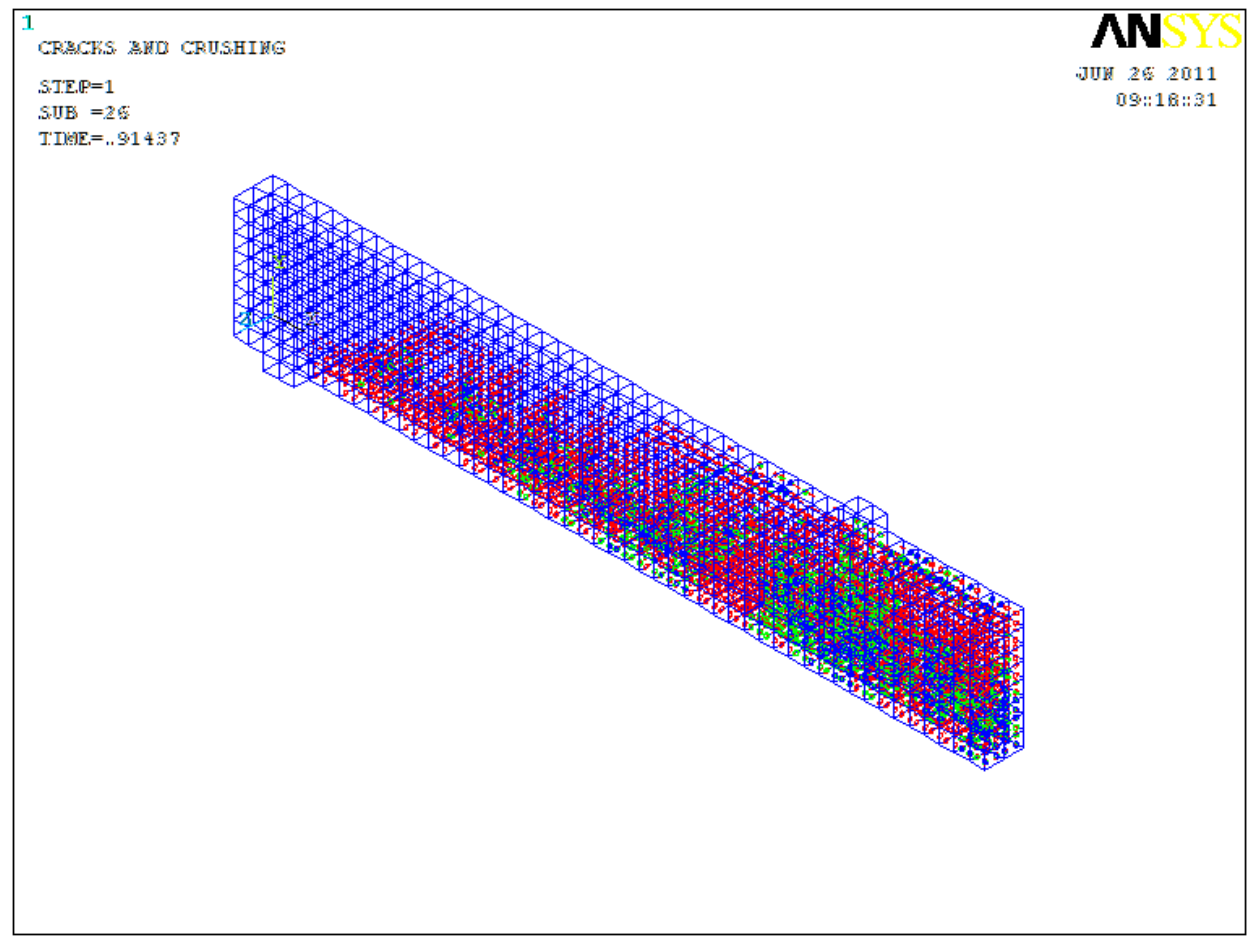

Figure 10: Crack patterns for concrete of Beam B1-CFRB at load 91.437kN.

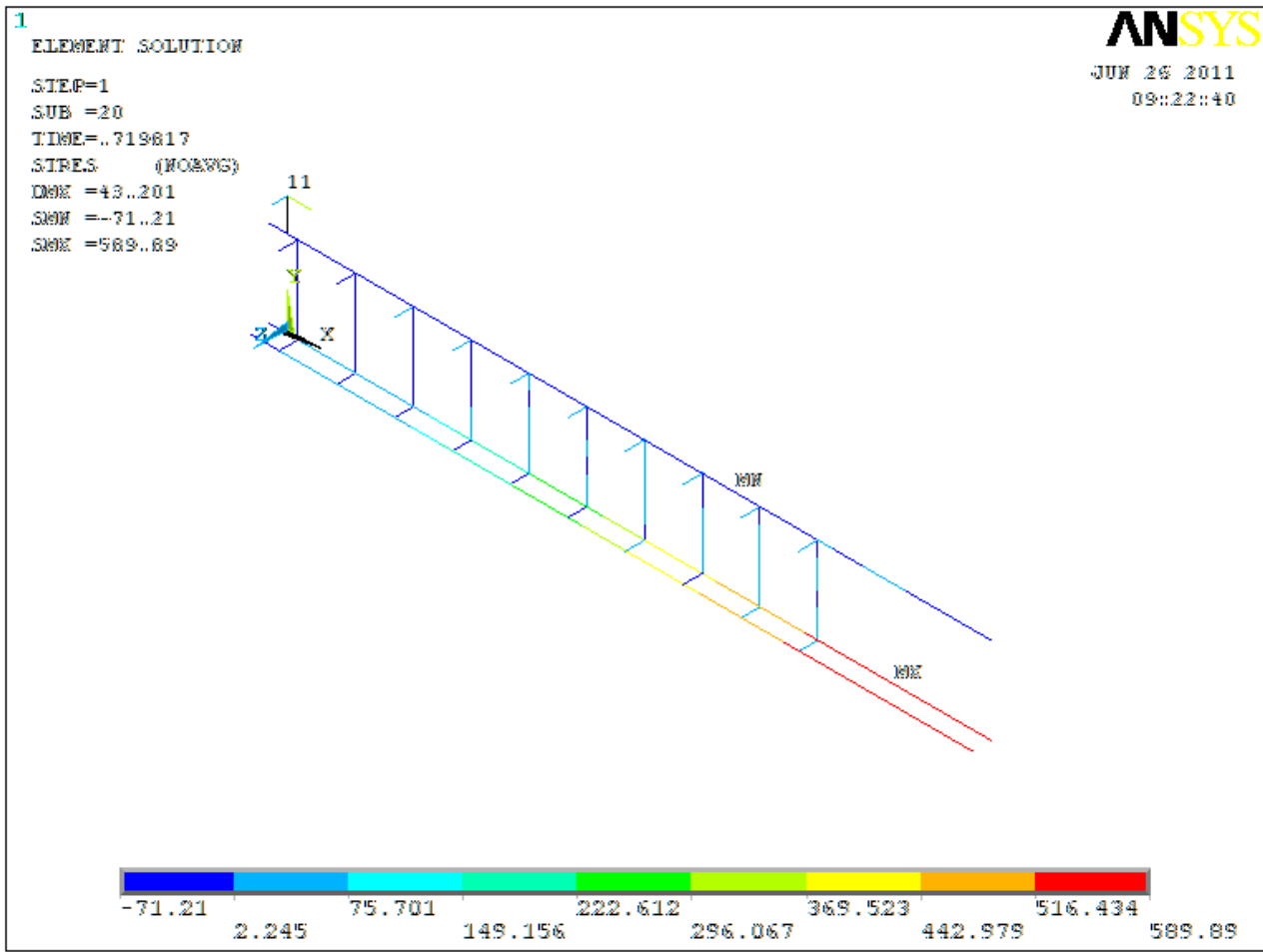

Figure 11: Reinforcement Stresses for Beam B1-Ferro-2 at Load 71.98kN. 


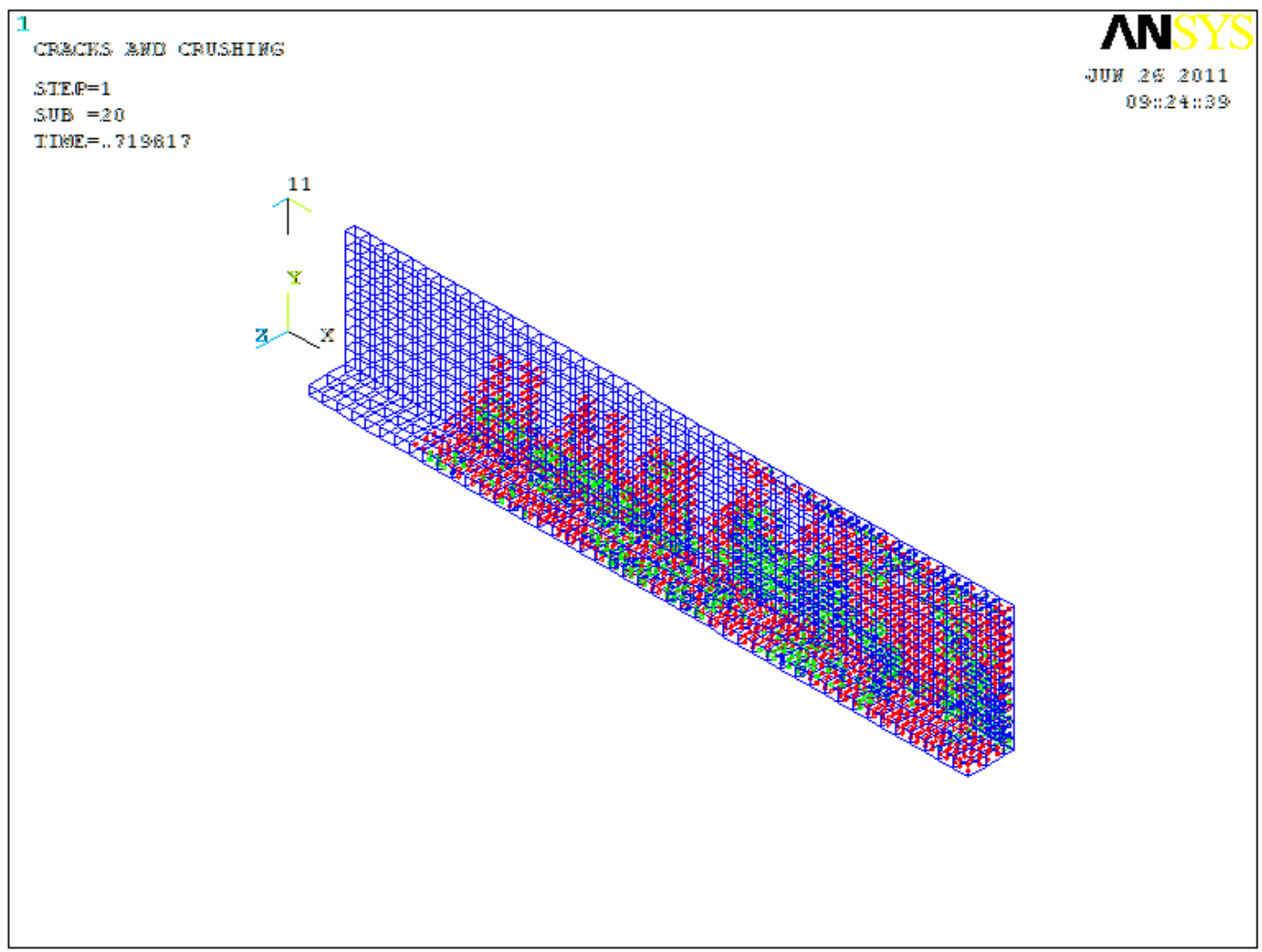

Figure 12: Crack patterns for mortar of Beam B1-Ferro-2 at load 71.98kN.

\section{Conclusions}

Based on the predicted results from the finite element analysis of reference beam and that of strengthened reinforced concrete beam by ferrocement using different numbers of wire meshes and CFRB laminate, the following conclusions may be drown:

1- The general predicted response, in terms of load deflection and ultimate load, of the finite element model shows a good agreement with the experimental beam results.

2- The addition of $(20 \mathrm{~mm})$ ferrocement jacket to the reference beam increases the ultimate load by about 7.5, 9 and 20 percent for ferrocement having 1, 2 and 3 wire mesh layers respectively; while using $(1 \mathrm{~mm})$ CFRB laminate enhanced the ultimate strength by $37.44 \%$ indicating the superiority of the CFRB to that of ferrocement jacket.

3- Strengthening the reinforced concrete beam by ferrocement jackets increased the deflection at ultimate load.

4- Deciding the superiority of which type of strengthening to be utilized requires an economical comparison between the two materials, ferrocement and CFRB laminates.

\section{References}

1- Andrews, G., Sharma, A.K., "Repaired Reinforced Concrete Beams" ACI, Concrete International, pp. 47-50,1998

2-Kaushik, S.K. and Dubey, A.K. " Performance Evaluation of RC Ferrocement Composite Beams", Proceedings of Fifth International Symposium, UMIST, pp 240- 256, 1994.

3-Nassif, H.H., Chirravuri, G. and Sanders, M.C. " Flexural Behavior of Ferrocement / Concrete Composite Beams" Ferrocement 6: Lambot Symposium, Proceedings of the 
Sixth International Symposium on Ferrocement, University of Michigan, Michigan USA, pp251 - 258, June 1998.

4-Vidivelli, B., Antiny Jeyasehar, C., and Srividya, P.R., " Repair and Rehabilitation of

Reinforced Concrete Beams by Ferrocement "Seventh International Symposium on Ferrocement and Thin Reinforced Cement Composites, National University of Singapore, 27-29, pp 465- 471, June2001.

5-Nassif, Hani H. and Najm, Husam, "Experimental and analytical Investigation of Ferrocement-Concrete Composite" Cement and Concrete Composite, Vol. 26, pp 787-796, 2004.

6-Seshu, D.R. “Flexural Behavior of Ferrocement Confined Reinforced Concrete (FCRC) Simply Supported Beams” Journal of Ferrocement: Vol. 30, No. 3, pp 261-273, July 2000.

7-Fahmy, Ezzat H. , Shaheen, Youysry B.I. and Korany Yasser, S. " Repairing Reinforced Concrete Beams by ferrocement” Journal of Ferrocement: Vol. 27, No. 1, pp 19-32, January 1997.

8- ANSYS, ANSYS Manual Set, 1998, ANSYS Inc., South point, 275 Technology Drive ,Canonsburg, PA 15317, USA.

9- William, K.J. and Warnke, E.D. "Constitutive Model for the Triaxial Behavior of Concrete", Proceedings of the International Association for Bridge and Structural Engineering, 1975, 19, p.174, ISMES, Bergamo, Italy.

10- ANSYS Manual, Version (10.0).

11- Fanning, P., "Nonlinear Models of Reinforced and Post-Tensioned Concrete Beams", 2001, Electronic Journal of Structural Engineering, 2, Website: www.civag.unimelb.edu.au/ejse.

12- Desayi, P. and Krishnan, S., "Equation for the stress-strain curve of concrete", Journal of the American Concrete Institute, Vol.61, March 1964, pp 345-350.

13- ACI 318m-05, American Concrete Institute,(2005) Building Code Requirements for Reinforced Concrete, American Concrete Institute, Farmington Hills, Michigan.

14-Ibrahim, A.M. and Mahmood, M.Sh., "Finite Element Modeling of Reinforced Concrete Beams Strengthened with FRP Laminates" European Journal of Scientific Research, Vol. 30, No. 4, pp 526-541, 2009. 